\title{
MODEL BLENDED LEARNING \\ DI PROGRAM STUDI PENDIDIKAN MATEMATIKA UNTIRTA
}

\author{
Anwar Mutaqin, Indiana Marethi, dan Syamsuri \\ FMIPA Universitas Sultan Ageng Tirtayasa \\ Email: anwar_mutaqin@untirta.ac.id
}

\begin{abstract}
Abstrak: Penelitian ini bertujuan meningkatkan pengetahuan bidang studi (content knowledge) sebagai unsur pembentuk kompetensi mahasiswa calon guru matematika dengan pembelajaran blended learning. Pengetahuan bidang studi dalam hal ini disebut hasil belajar. Desain penelitian menggunakan kuasi eksperimen karena akan membandingkan pengaruh suatu perlakuan. Teknik pengumpulan data dilakukan dengan tes. Untuk uji persyaratan normalitas, digunakan uji Kolmogorov-Smirnov, sedangkan uji homogenitas digunakan uji Levene. Untuk mengetahui perbedaan rerata, digunakan uji-t jika data berdistribusi normal. Sementara, jika data tidak berdistribusi normal digunakan uji Mann-Whitney. Hasil tes akhir pembelajaran dibandingkan untuk mengetahui pengaruh blended learning terhadap hasil belajar. Hasil pengolahan data menunjukkan bahwa hasil belajar kelas blended learning lebih baik daripada kelas biasa. Selain itu, mahasiswa blended learning lebih aktif mengerjakan tugas daripada kelas biasa.
\end{abstract}

Kata Kunci: blended learning, calon guru matematika, content knowledge

\section{A BLENDED LEARNING MODEL IN THE MATHEMATICS EDUCATION STUDY PROGRAM IN UNTIRTA}

\begin{abstract}
This study was aimed to improve the content knowledge as an element for developing students' competence through blended learning. In this study, this content knowledge is called learning achievement. The study used the experimental design. The data were collected using a test. To test the normality of data distribution, the Kolmogorov-Smirnov test was utilized, while to test the homogeneity of the variances, the Levene's test was used. To test the hypothesis, the t-test was used. The findings showed that the learning achievement of the students taught using blended learning was better than that of those taught using the conventional method. In addition, the students taught using the blended learning were more active in doing the assignment than those in the conventional class.
\end{abstract}

Kata Kunci: blended learning, mathematics students, content knowledge

\section{PENDAHULUAN}

Kemampuan dan keterampilan yang dibutuhkan untuk dapat bersaing secara global senantiasa berubah setiap dekade. Beberapa kemampuan yang dahulu dibutuhkan, sekarang kurang dibutuhkan karena dapat digantikan oleh peralatan teknologi. Di sisi lain, kebutuhan terhadap kemampuan tertentu semakin meningkat. Gambar 1 merupakan hasil penelitian Levy dan Murnane (Koenig, 2011) yang menunjukkan perubahan kebutuhan skill yang dibutuhkan pada abad ke-21.

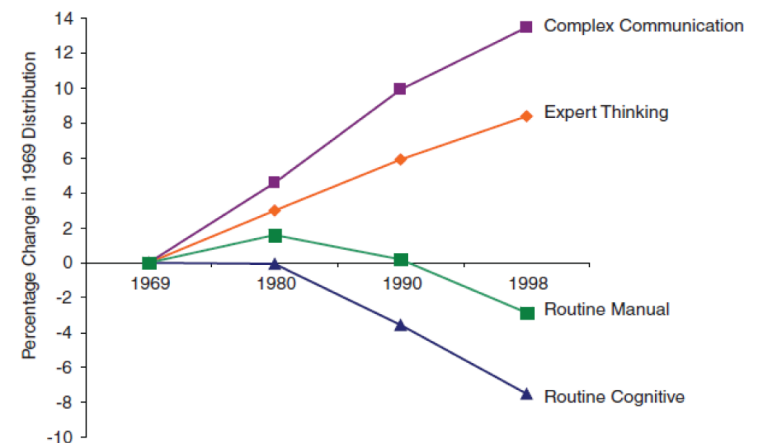

Gambar 1: Perubahan Kebutuhan Skill yang Dibutuhkan pada Abad ke-21

Levy dan Murnane selanjutnya mendefinisikan masing-masing kemampuan tersebut 
sebagai berikut: (a) routine cognitive tasks, seperti pengarsipan; (b) routine manual tasks, sepertimengkoordinasi pekerjaan; (c) tugas-tugas yang memerlukan expert thinking, seperti mengidentifikasi dan menyelesaikan masalah baru; (d) tugastugas yang memerlukan complex communication, seperti pekerjaan yang melibatkan informasi yang kritis dan menyampaikan hal untuk meyakinkan audien tentang masalah interpretasi.

Dalam rangka mengantisipasi perubahan tersebut, lembaga pendidikan di Indonesia, dari sekolah dasar sampai perguruan tinggi, harus mampu menghasilkan lulusan yang mampu beradaptasi dengan kebutuhan jamannya. Lulusan lembaga pendidikan harus memiliki kemampuan: (a) beradaptasi dengan perubahan yang lebih cepat dari sebelumnya; (b) beradaptasi dengan pekerjaan yang akan diciptakan kemudian; (c) menggunakan teknologi yang akan ditemukan, dan 4) menyelesaikan masalah yang akan muncul kemudian.

Kemampuan-kemampuan tersebut dapat dilatih/difasilitasi melalui pembelajaran matematika. Kilpatrick et al (2001) mengemukakan bahwa tujuan pembelajaran matematika adalah agar siswa memiliki kecakapan matematis (mathematical proficiency) yang mencakup lima hal, yaitu: pemahaman konsep (conceptual understanding), kelancaran dalam melakukan prosedur (procedural fluency), memiliki kompetensi yang strategis (strategic competence), penalaran yang adaptif (adaptive reasoning), dan disposisi yang produktif (productive disposition). Sejalan dengan hal tersebut, pemerintah melalui Permendiknas Nomor 22 tahun 2006 menetapkan tujuan pembelajaran matematika yang merupakan panduan bagi setiap guru matematika di tingkat sekolah.

Tujuan pembelajaran matematika yang dimaksud akan tercapai jika guru matematika memiliki kompetensi yang memadai dalam melakukan pembelajaran yang sesuai dengan kurikulum yang ditetapkan. Peran guru sangat penting dalam menentukan keberhasilan kurikulum yang telah ditetapkan oleh pemerintah. Anita Lie mengibaratkan kurikulum adalah kendaraan, sementara guru adalah pengendaranya (Kompas, 20/2/2013). Pemerintah melalui Permendiknas Nomor 16 Tahun 2007 telah menetapkan kompetensi yang harus dikuasai guru, yaitu: kompetensi pedagogis, kepribadian, sosial, dan profesional.
Namun, uji kompetensi guru yang dilakukan tahun 2012 menunjukkan kompetensi mereka masih sangat rendah. Menteri Pendidikan dan Kebudayaan waktu itu, Mohammad Nuh, membeberkan hasil rata-rata Uji Kompetensi Awal (UKA) 2012 yaitu 42,25 dengan nilai tertinggi 97,0 dan nilai terendah 1,0 (Kompas online, 12/3/2012). Hasil rata-rata UKA itu mencakup seluruh peserta (guru) dari jenjang TK sampai jenjang SMA. Dengan kondisi seperti ini, sulit mengharapkan kecakapan matematika siswa menjadi lebih baik.

Berbagai upaya untuk meningkatkan kompetensi dan profesionalisme guru matematika sudah banyak dilakukan. Pembinaan profesionalisme di tingkat kabupaten atau kota sering tidak menyentuh kebutuhan, guru masih dilihat dari kaca mata birokrasi, bukan akademisi Akibatnya, guru lebih banyak dibekali dengan kemampuan administrasi dalam pembelajaran. Kompetensi pedagogis dan profesional guru belum tersentuh. Upaya lainnya yang dilakuan pemerintah adalah meningkatkan kesejahteraan guru dengan sertifikasi guru. Sayangnya, menurut Survey Bank Dunia tahun 2009, 2011, dan 2012, sertifikasi guru belum mampu meningkatkan prestasi guru dan siswa secara signifikan (Kompas, 18/12/2012). Selain itu, hasil observasi pendahuluan dan wawancara terhadap beberapa guru matematika SMA peserta Pendidikan dan Latihan Profesionalisme Guru (PLPG) di Banten menyatakan bahwa pelatihan-pelatihan yang pernah dilakukan tidak pernah diaplikasikan ketika mengajar.

Berdasarkan fakta-fakta tersebut sulit meningkatkan kompetensi guru matematika hanya berdasarkan pelatihan-pelatihan yang waktunya terbatas seperti yang selama ini diikuti guru. Banyak guru matematika yang saat ini mengajar tidak memiliki kompetensi yang memadai. Akibatnya, pelatihan untuk meningkatkan kompetensi guru tidak optimal. Selain itu, tidak ada evaluasi yang mendasar setelah pelaksanaan pelatihan. Meskipun demikian pelatihan itu tetap harus dilakukan karena hanya itu usaha yang bisa dilakukan terhadap guru-guru yang saat ini sudah mengajar.

Upaya lainnya adalah memperbaiki kualitas lulusan Lembaga Pendidik dan Tenaga Kependidikan (LPTK), khususnya dari Program Studi 
Pendidikan Matematika. Membentuk mahasiswa calon guru matematika yang kompeten lebih mudah daripada meningkatkan kompetensi guru matematika yang sudah mengajar. Mahasiswa lebih mudah diarahkan dan diberi beban belajar yang lebih banyak daripada guru.

Salah satu upaya tersebut adalah dengan memanfaatkan internet untuk pendidikan yang dikenal sebagai e-learning. Manfaat internet bagi pendidikan adalah dapat menjadi akses kepada sumber informasi, akses kepada nara sumber, dan sebagai media kerjasama. Selain itu, pemanfaatan fasilitas internet tidak dibatasi ruang dan waktu, sehingga pertukaran informasi dan ilmu pengatahuan di antara mahasiswa dan dosen dapat berlangsung di mana saja dan kapan saja.

Salah satu bentuk pemanfaatan internet untuk lembaga pendidikan adalah model blended learning. Model ini memadukan pembelajaran secara tatap muka (tradisional) dengan e-learning. Dengan cara ini, kelebihan masing-masing metode dapat dimanfaatkan secara optimal. Pertemuan tatap muka di kelas dapat dimanfaatkan untuk mendiskusikan bahan-bahan yang tersedia di sistem e-learning. Hal ini memacu mahasiswa untuk mampu mengatur ritme belajar yang tidak hanya di dalam kelas, tetapi juga di luar kelas melalui sistem blended learning tersebut.

Pengembangan blended learning di lembaga pendidikan membutuhkan sebuah sistem (aplikasi) yang disebut Learning Management System (LMS), seperti moodle (Krunger-Ross et al, 2013). LMS merupakan aplikasi yang menjadikan tahapan pembelajaran memenuhi konsep pemanfaatan e-learning. Sebagai sebuah aplikasi untuk e-learning, LMS berfungsi mengotomasi dan memvirtualisasi diskusi secara elektronik. Fungsinya mirip dengan fungsi administrasi dalam sebuah sekolah. Dengan LMS dapat diatur pengguna yang berhak untuk mengikuti sebuah forum diskusi, materi yang perlu didiskusikan, masa berlaku kelas, mengunggah video pembelajaran, dan lain sebagainya. Aplikasi LMS yang bersifat open source (gratis) dan sangat banyak digunakan di dunia saat ini adalah Moodle.

Tentang Kompetensi. Kompetensi oleh McAshan (Mulyasa, 2002) diartikan sebagai pengetahuan keterampilan dan kemampuan yang dikuasai oleh seseorang yang telah menjadi bagian dari dirinya, sehingga ia dapat melakukan perilaku-perilaku kognitif, afektif, dan psikomotorik dengan sebaik-baiknya. Sejalan dengan itu, Finch \& Crunkilton (Mulyasa, 2002) mengartikan kompetensi sebagai penguasaan terhadap suatu tugas, keterampilan, sikap, dan apresiasi yang diperlukan untuk menunjang keberhasilan. Dalam UU No. 14 Tahun 2005 tentang Guru dan Dosen disebutkan bahwa kompetensi adalah seperangkat pengetahuan, keterampilan, dan perilaku yang harus dimiliki, dihayati, dikuasai, dan diaktualisasikan oleh guru dalam melaksanakan tugas keprofesionalan. Dalam undang-undang tersebut juga disebutkan bahwa guru harus memiliki empat kompetensi, yaitu: kompetensi pedagogis, kompetensi kepribadian, kompetensi sosial, dan kompetensi profesional.

Shulman (1987:8) mengemukakan bahwa basis pengetahuan guru mencakup tujuh kategori, yaitu: 1) pengetahun tentang bidang studi (content knowledge); 2) pengetahuan tentang pembelajaran (general pedagogical knowledge); 3) pengetahuan tentang cara mengajarkan bidang studinya (pedagogical content knowledge); 4) pengetahuan tentang kurikulum (curriculum knowledge); 5) pengetahuan tentang siswa dan karakteristiknya (knowlegde of learners and their characteristics); 6) pengetahuan tentang konteks pendidikan (knowledge of educational context); dan 7) pengetahuan tentang tujuan, nilai, dan basis filosofi dan sejarah pendidikan (knowledge of educational ends, purposes, and values, and their philosophical and historical grounds).

Dari ketujuh kategori tersebut, pedagogical content knowledge (PCK) lebih spesial karena hal itu membedakan antara seorang ahli pada disiplin dan guru. Dalam konteks calon guru matematika, PCK membedakan antara ahli matematika dan guru matematika. Namun demikian, penguasaan konten matematika juga penting untuk membangun PCK. Shulman (1986) mengidentifikasi dua komponen penting dalam PCK yang harus dikuasai calon guru matematika, yaitu pengetahuan tentang strategi pembelajaran matematika dan representasinya dan pengetahuan tentang konsepsi (atau miskonsepsi) matematika yang ada di pikiran siswa.

Dalam penelitian ini, pengetahuan bidang studi akan diukur berdasarkan ujian yang biasa 
dilakuakan pada akhir pembelajaran. Kompetensi bidang studi yang diujikan adalah kecakapan matematis yang meliputi: pemahaman konsep, kelancaran dalam melakukan prosedur, penalaran yang adaptif, kompetensi yang strategis, dan disposisi yang produkti. Pengetahuan bidang studi karena pembelajaran blended learning diterapkan pada satu mata kuliah, yaitu Aljabar Matriks, sehingga tidak memungkinkan untuk mengukur PCK.

Upaya meningkatkan kualitas calon guru matematika harus selalu dilakukan sehingga memberi dampak bagi kemajuan pendidikan matematika. Calon guru matematika, seperti halnya guru matematika, dituntut menguasai tujuh aspek keterampilan untuk menjadi guru matematika yang profesional, dua diantaranya yang paling dibutuhkan adalah penguasaan terhadap content knowledge dan pedagogical content knowledge. Content knowledge merupakan kemampuan dalam bidang matematika, sedangkan pedagogical content knowledge adalah kemampuan untuk menguasai matematika sekaligus cara mengajarkannya.

Minat siswa-siswa Indonesia untuk menjadi guru meningkat drastis seiring dengan program sertifikasi guru. Ini merupakan peluang emas untuk mencetak guru yang kompeten, karena siswa yang masuk ke LPTK merupakan dengan kemampuan lebih baik dari tahun-tahun sebelumnya. Namun, hal ini juga harus diimbangi dengan program pembelajaran yang memadai, sehingga mahasiswa dapat meningkatkan kompetensi yang dibutuhkan untuk menjadi guru.

Atas dasar itu, diperlukan suatu sistem pembelajaran blended learning di Program Studi Pendidikan Matematika untuk memperluas interaksi dengan sesama mahasiswa maupun mahasiswa dengan dosen. Selain itu, sistem blended learning juga memperluas kesempatan belajar yang tidak dibatasi oleh ruang dan waktu. Hal ini karena sistem blended learning memadukan pembelajaran tatap muka di kelas dengan pemanfaatan internet melalui e-learning.

Tentang blended learning. Dalam satu dekade terakhir blended learning telah menjadi tren dalam dunia pendidikan, baik peneliti dosen maupun peneliti untuk keperluan tesis dan disertasi. Drysdale et al (2013) mencatat sejak 2001 ada 205 tesis dan disertasi yang mengambil topik blended learning dan sudah dipublikasi. Fokus penelitian yang dilakukan di pendidikan tinggi, kinerja siswa dan mahasiswa, dan membandingkan efektifitas blended learning dengan model pembelajaran lain. Hal ini merupakan respon banyak pihak terhadap perkembangan teknologi informasi dan komunikasi yang sangat pesat dan merambah ke berbagai bidang, termasuk bidang pendidikan.

Banyak definisi blended learning dikemukaan oleh para peneliti. Curtis, et al. (2005) menyatakan tiga hal yang harus ada dalam blended learning: mengkombinasikan keunggulan setiap pengajaran, mengkombinasikan berbagai metode pembelajaran, dan menggabungkan pembelajaran online dengan tradisional. Dziuban, et al (2004) mencatat bahwa blended learning harus dipandang sebagai pendekatan yang mengkombinasikan efektifitas dan kesempatan sosialisasi dengan peningkatan lingkungan teknologi online. Dengan kata lain, blended learning harus dipandang sebagai rancang ulang model pembelajaran dengan karakteristik: 1) perubahan dari pembelajaran yang berpusat pada dosen menjadi menjadi pembelajaran yang berpusat pada mahasiswa, dan 2) meningkatnya interaksi antara mahasiswa dengan dosen, mahasiswa dengan mahasiswa, mahasiswa dengan bahan ajar, dan mahasiswa dengan sumber belajar lain. Pada penelitian ini blended learning didefinisikan sebagai metode pembelajaran yang menyediakan mahasiswa dan dosen untuk belajar dan memecahkan masalah bersama dengan bantuan Learning Management System (LMS), diskusi di kelas, dan bantuan alat komunikasi mobile (Yen dan Lee, 2011).

Hasil penelitian Weibel danWissmath (2011) menunjukkan bahwa penerapan blended learning meningkatkan kinerja mahasiswa tanpa memberi beban kerja tidak banyak dan memberikan umpan balik yang memadai bagi proses belajar mahasiswa. Hal ini berbeda jauh dengan pembelajaran yang murni online, di mana beban kerja mahasiswa semakin berat dan banyak yang drop out dari proses pembelajaran. Senada dengan hal tersebut, hasil penelitian López-Pérez et al (2011) menunjukkan bahwa penerapan blended learning mengurangi laju drop out mahasiswa dan sekaligus meningkatkan nilai akhir ujian. 
Selain itu, motivasi dan kepuasan mahasiswa juga meningkat. Akibatnya mahasiswa memiliki sikap (attitude) yang postif terhadap pembelajaran. Penelitian berbasis website yang dilakukan Chandra dan Watters (2011) menunjukkan bahwa hasil belajar mahasiswa meningkat dan sikap mahasiswapositif dalam belajar.

Berdasarkan hasil-hasil penelitian dari berbagai negara, blended learning sangat potensial untuk meningkatkan kompetensi calon guru matematika di Prodi Pendidikan Matematika. Namun, perlu dirancang sebuah sistem yang baik, sehingga efektif dalam pelaksanaan dan hasilnya memuaskan. Sistem blended learning yang akan dikerjakan dalam penelitian ini menggunakan LMS moodle. Mahasiswa diberi akun sebagai bagian dari LMS. Bahan ajar, slide, ruang diskusi, tugas, dan pengumpulan tugas disediakan di LMS ini. Selain itu, keterlibatan mahasiswa dalam LMS dikontrol melalui rekaman durasi dalam mengakses LMS. Pembelajaran di kelas secara tatap muka digunakan untuk diskusi dengan dosen.

Dengan sistem ini, mahasiswa belajar tidak terbatas ruang dan waktu. Mereka juga dapat bertukar informasi dengan sesama mahasiswa maupun dengan dosen. Mahasiswa juga diharapkan dapat mengatur ritme belajarnya sendiri. Hal ini akan meningkatkan kemadirian mahasiswa (self regulated learning) dalam belajar. Dengan cara seperti ini, kompetensi mahasiswa sebagai calon guru matematika diharapkan meningkat.

\section{METODE}

Subjek penelitian ini adalah mahasiswa Program Studi Pendidikan Matematika. Populasi penelitian ini adalah mahasiswa Jurusan Pendidikan Matematika UNTIRTA. Mahasiswa yang menjadi subjek penelitian adalah mahasiswa yang mengikuti perkuliahan Aljabar Matriks. Sampel pada penelitian ini terdiri dari dua kelompok mahasiswa yang dipilih secara purposive. Pengambilan sampel secara purposive bertujuan untuk mendapatkan kelas yang memiliki kemampuan awal pembuktian matematis yang tidak berbeda secara signifikan. Sampel yang terpilih untuk kelas eksperimen sebanyak 30 orang, sedang kelas kontrol sebanyak 25 orang.
Metode penelitian yang digunakan adalah kuasi eksperimen karena untuk mengetahui pengaruh suatu perlakuan terhadap suatu variabel terikat yang dapat diukur, yaitu pembelajaran model blended learning terhadap hasil belajar mahasiswa, dalam hal ini pengetahuan bidang studi. Kuasi eksperimen dipilih karena subjek tidak dikelompokkan secara acak, tetapi peneliti menerima keadaan subjek seadanya (Ruseffendi, 2005:52). Dalam penelitian ini subjek penelitian dibagi menjadi dua kelompok, yaitu kelompok eksperimen dan kelompok kontrol. Kelompok eksperimen (kelas perlakuan) merupakan kelompok mahasiswa yang diberi pembelajaran blended learning, sedangkan kelompok kontrol (kelas pembanding) adalah kelompok mahasiswa yang diberi pembelajaran biasa.

Desain penelitian yang digunakan adalah posttest control group. Desain tersebut dapat digambarkan sebagai berikut:

Kelompok Eksperimen :
Kelompok Kontrol $\quad$ X

Data hasil postes diolah dengan statistika inferensial. Untuk uji persyaratan normalitas, digunakan uji Kolmogorov-Smirnov, sedangkan uji homogenitas digunakan uji Levene. Untuk mengetahui perbedaan rerata, digunakan uji-t jika data berdistribusi normal. Sementara, jika data tidak berdistribusi normal digunakan uji Mann-Whitney.

\section{HASIL DAN PEMBAHASAN Hasil}

Hasil uji kelayakan meliputi dua hal, yaitu data hasil tes akhir pembelajaran dan analisis terhadap pelaksanaan blended learning berdasarkan hasil wawancara dengan mahasiswa. Data tes akhir pembelajaran disajikan dalam Tabel 1 .

Tabel 2 menyajikan data hasil tes akhir pembelajaran dalam ukuran pemusatan dan penyebaran data. 
Tabel 1. Data Hasil Tes Akhir Pembelajaran

\begin{tabular}{lllll}
\hline \multirow{2}{*}{ Batang } & \multicolumn{2}{l}{ Kelas BL } & \multicolumn{2}{c}{ Kelas Biasa } \\
\cline { 2 - 5 } & Daun & Frekuensi & Daun & Frekuensi \\
\hline 1 & - & 0 & 67 & 2 \\
2 & 77 & 2 & 233458 & 6 \\
3 & 6 & 1 & 022478 & 6 \\
4 & 048 & 3 & 99 & 2 \\
5 & 23889 & 5 & 0255789 & 7 \\
6 & 2359 & 4 & 01 & 2 \\
7 & 23556688889 & 11 & - & 0 \\
8 & 25 & 2 & - & 0 \\
9 & 27 & 2 & - & 0 \\
\hline
\end{tabular}

Tabel 2. Data Hasil Tes Akhir Pembelajaran

\begin{tabular}{lcc}
\hline Statistik & $\begin{array}{c}\text { Kelas } \\
\text { Blended } \\
\text { learning }\end{array}$ & Kelas Biasa \\
\hline N & 30 & 25 \\
Nilai Terendah & 2,7 & 1,6 \\
Nilai Tertinggi & 9,7 & 6,1 \\
Rerata & 6,57 & 3,94 \\
SB & 1,81 & 1,52 \\
Kuartil Bawah & 5,3 & 2,4 \\
Median & 7,1 & 3,7 \\
Kuartil Atas & 7,8 & 5,5 \\
Modus & 7,8 & - \\
\hline
\end{tabular}

Sebagaimana terlihat pada Tabel 2, nilai mahasiswa cukup memuaskan mengingat pembelajaran dengan blended learning baru pertama kali diikuti mahasiswa. Data kuartil menunjukkan bahwa $25 \%$ nilai mahasiswa di bawah 5,3 dan $25 \%$ nilai mahasiswa di atas 7,8 . Di kelas biasa, sebanyak $75 \%$ mahasiswa memiliki nilai di bawah 5,5 (kuartil atas), sementara di kelas blended learning, sebanyak $75 \%$ mahasiswa memiliki nilai 5,3 (kuartil bawah). Dengan demikian, data nilai kelas blended learning jauh lebih baik daripada kelas dengan pembelajaran biasa.

Meskipun demikian, perlu dilakukan pengujian dengan statistika inferensial untuk mengetahui apakah hasil tersebut dapat berlaku untuk populasi. Untuk keperluan tersebut, uji Kolmogorov-Smirnov dilakukan untuk memeriksa distribusi data. Hasil penghitungan diperoleh nilai signifikansi (nilai-p) untuk kelas blended learning dan kelas biasa berturut turut 0,69 dan 0,53. Ini berararti data berdistribusi normal pada taraf sinifikansi $5 \%$. Selanjutnya uji Levene dilakukan untuk mengetahui variansi data. Hasil pengujian diperoleh nilai signifikansi sebesar 0,669. Ini berarti data bervariansi homogen.

Selanjutnya, hipotesis penelitian diuji dengan uji-t satu pihak untuk data homogen. Hasil penghitungan diperoleh nilai signifikansi 0,000. Ini berarti $\mathrm{H}_{0}$ ditolak. Dengan demikian, hasil belajar mahasiswa kelas blended learning lebih baik daripada kelas biasa.

\section{Pembahasan}

Nilai ujian akhir kelas blended learning lebih baik daripada kelas biasa disebabkan mahasiswa kelas blended lebih rajin mengerjakan pekerjaan rumah daripada kelas biasa. Hal ini sejalan dengan penelitian Benta et al (2014) yang menyatakan bahwa penggunaan Moodle dalam pembelajaran meningkatkan aktivitas kerja laboratorium dan pekerjaan rumah. Tugas yang diberikan kepada mahasiswa harus diketik dan diunggah melalui LMS. Hal ini memberi kesempatan mahasiswa belajar lebih banyak, karena tugas yang diketik lebih membutuhkan waktu lama daripada tulis tangan. Selain itu, tugas yang dketik menyebabkan mahasiswa beberapa kali melakukan penyuntingan tulisan yang membuat mereka membaca ulang tugas tersebut.

Shen dan Huang (2006) mengemukakan bahwa penggunaan Moodle sebagai platform blended learning dapat membantu mahasiswa membangun skema kognitif, mengkonstruksi pengetahuan, dan menanamkan sikap positif selama diskusi dengan teman sebaya maupun dosen. Mereka hadir di kelas lebih siap dengan materi yang akan didiskusikan pada saat perkuliahan tatap muka dengan dosen di kelas. Hal ini karena materi perkuliahan dalam bentuk bahan cetak maupun video pembelajaran sudah diunggah terlebih dahulu di LMS. Kondisi demikian 
berbeda dengan kelas biasa yang menunggu dosen menjelaskan untuk terlibat diskusi.

Kebiasaan mahasiswa blended learning yang selalu mengakses internet untuk masuk ke LMS dalam rangka mengunduh bahan ajar dan tugas serta mengumpulkan tugas dan kuis turut meningkatkan literasi komputer mereka. Akibatnya, mereka tidak puas hanya mengunduh dari LMS, tetapi mencari bahan lagi melalui mesin pencari (search engine). Hal ini turut meningkatkan pengetahuan dan pengalaman dalam mempelajari bahan kuliah.

Hasil pengamatan data mahasiswa yang akses ke LMS diperoleh bahwa mahasiswa akses ke LMS untuk mengunduh bahan ajar, tugas, dan mengerjakan kuis, dan mengunggah jawaban tugas. Selain itu, mereka membaca bahan ajar yang disediakan melalui fasilitas Page. Mereka tidak terlibat dalam diskusi online, padahal setiap pekan disediakan fasilitas tersebut.

Data yang terekam di LMS menunjukkan bahwa mereka akses ke LMS menjelang perkuliahan tatap muka dilaksanakan. Hal ini disebabkan bahan ajar, tugas, dan kuis diunggah pada saat menjelang perkuliahan tatap muka di kelas. Setelah itu mahasiswa yang mengakses ke LMS berkurang sampai waktunya mengumpulkan kuis dan tugas. Antara kedua waktu tersebut, ada beberapa mahasiswa yang akses karena ingin melihat komentar di kuis dan tugas yang mereka unggah.

Berdasarkan wawancara dengan mahasiswa, mereka mengunduh semua video pembelajaran dan bahan ajar yang tersedia di LMS. Mahasiswa yang lebih menyukai pembelajaran dari video adalah $30 \%$, sedangkan sisanya lebih menyukai bahan ajar dalam bentuk tulisan. Mereka lebih menyukai bahan ajar dalam tulisan karena mereka belajar langsung dan sambil membuat catatan kecil di bahan ajar tersebut. Sementara, mereka kurang menyukai video pembelajaran karena durasinya lama dan tidak bisa langsung mencatat. Namun demikian, mereka menonton video pembelajaran tertentu jika ada materi yang tidak dipahami pada bahan ajar bentuk tulisan.

Mahasiswa tidak aktif dalam diskusi online karena secara umum mereka tidak terbiasa menulis. Mereka khawatir pertanyaan yang tulis berbeda dengan maksud yang diinginkan. Selain itu, mahasiswa umumnya menunggu rekannya yang bertanya melalui diskusi online. Namun, masalah ini diatasi dengan diskusi di kelas pada saat perkuliahan tatap muka dengan dosen pengampu mata kuliah.

Hasil penelitian menunjukkan adanya kesesuaian dengan penelitian Budiharti dkk (2015) tentang penggunaan blended learning di SMP yang menyimpulkan bahwa penggunaan media Moodle pada pembelajaran IPA Terpadu dengan tema Pelestarian Lingkungan dapat meningkatkan kemampuan kognitif siswa SMP dengan besarnya persentase ketuntasan siswa yaitu $50,7 \%$ pada siklus I dan $78,76 \%$ pada siklus II. Jadi, bahkan di level SMP pun pembelajaran dengan menggunakan model blended learning sudah cukup berpengaruh.

\section{SIMPULAN}

Berdasarkan hasil penelitian yang diperoleh, dapat disimpulkan mahasiswa kelas blended learning lebih baik daripada mahasiswa kelas biasa. Selain itu, mahasiswa kelas blended learning lebih aktif mengerjakan tugas daripada kelas biasa

\section{UCAPAN TERIMA KASIH}

Ucapan terima kasih disampaikan kepada sejawat dan berbagai pihak yang telah membantu terselenggarakannya penelitian ini sehingga selesai. Mudaha-mudahan penelitin ini ada manfaatnya.

\section{DAFTAR PUSTAKA}

Benta, D., Bologa, G., Dzitac, I. 2014.E-learning Platforms in Higher Education. Case Study. Procedia Computer Science 31, 1170 1176.

Budiharti, Rini, Elvin Yusliana Ekawati, Pujayanto, Daru Wahyuningsih, \&Fairusy Fitria H. 2015. "Penggunaan Blended Learning dengan Media Moodle untuk Meningkatkan Kemampuan Kognitif Siswa SMP", Cakrawala Pendidikan, Th XXX!V, No. 1, hlm.

Chandra, V dan Watters, J. J. 2012. Re-thinking physics teaching with web-based learning. Computers \& Education 58, 631-640. 
Curtis, J. B., Graham, C. R., Cross, J., \& Moore, M. G. 2005. The handbook of blended learning: Global perspectives, local designs. Pfeiffer \& Company.

Drysdale, J. S., Graham, C. R., Spring, K. J., Halverson, L. R.2013. An analysis of research trends in dissertations and theses studying blended learning. Internet and Higher Education 17, 90-100.

Dziuban, C. D., Hartman, J. L., \& Moskal, P. D. 2004. Blended learning. EDUCAUSE Center for Applied Research Bulletin 7, 1-12.

Kilpatrick, J., Swafford, J., Findell, B. 2001. Adding it-up: Helping Children Learn Mathematics. Washington D.C: The National Academies Press.

Koenig, J. A. 2011. Assessing 21th century skills. Washington D.C: The National Academies Press.

Krunger, Matthew J., dan Waters, R. D. 2013. Predicting online learning success: applying the situasional theory of publics to the virtual classroom. Computer \& Education 61, 176-184.
López-Pérez, M. V., Pérez-López, M., dan Rodríguez-Ariza, L. 2011. Blended learning in higher education: Students' perceptions and their relation to outcomes. Computers \& Education 56, 818-826.

Ruseffendi, E. T. 2005. Dasar-dasar penelitian pendidikan dan Bidang Non-Eksakta Lainnya. Bandung: Transito.

Shen, C.-H., Huang, X.-Y. 2006. The application of Moodle for Web-based peer assessment, Journal of Educational Media \&Library Sciences, 43(3), 267-284.

Shulman, L. S. 1987. Knowledge and Teaching: Foundations of The New Reform.Harvard Educational Review 57, 1-21.

Weibel, D. danWissmath, B. 2011. Efficient learning using a virtual learning environment in a university class. Computers \& Education $56,495-504$.

Yen, Jung-Chuan dan Lee, Chun-Yi. 2011. Exploring problem solving patterns and their impact on learning achievement ina blended learning environment. Computers \& Education 56. 138-145. 